\title{
Review Artikel: Metode untuk Meningkatkan Absorpsi Obat Transdermal
}

\author{
Viviane Annisa*1 \\ ${ }^{1}$ Pasca Sarjana Farmasi Universitas Gadjah Mada, Sekip Utara, Sleman, Yogyakarta, 55821 \\ *E-mail: vivianeannisa@ mail.ugm.ac.id
}

\begin{abstract}
The route of administration of transdermal drugs is preferred because it is easy to use. However, there are limitations associated with the difficulty of drugs penetrating into the skin. This is caused by the presence of the stratum corneum which is the main barrier for drug entry into the skin. Penetration of the drug into the skin can be through the trans-epidermal (transcellular and paracellular) route and the trans-appendegeal route depending on the dosage form. To increase the penetration ability of transdermal drugs, it can use chemical enhancers and physical enhancers. Chemical enhancers can be classified based on chemical structure or based on the mechanism of action. Chemical compounds that have the same functional groups can have different mechanisms of action depending on the physical-chemical nature. Chemical enhancers are categorized based on their chemical structure, including: water, alcohol, amides, esters, alcohol ethers, pyrrolidone, hydrocarbons, sulfides, surfactants, terpenes, phospholipids, vesicles. Whereas physical enhancers in the form of drug delivery use external energy to encourage or physically damage the stratum corneum. Physical enhancer methods such as Iontophoresis, Electroporation, Magnetophoresis, Sonophoresis, Photomechanics, Radiofrequency, Thermophoresis, Microneedle, and Jet Injectors.
\end{abstract}

Keyword: transdermal; permeation enhancer; chemical enhancer; physical enhancer

\begin{abstract}
ABSTRAK
Rute pemberian obat transdermal lebih disukai karena mudah dalam penggunaannya. Namun, terdapat keterbatasan terkait dengan sulitnya obat penetrasi ke dalam kulit. Hal ini disebabkan oleh adanya stratum korneum yang menjadi barier utama masuknya obat ke dalam kulit. Penetrasi obat ke dalam kulit dapat melalui rute trans-epidermal (trans-selular dan paraselular) dan rute trans-appendegeal. Untuk meningkatkan kemampuan penetrasi obat transdermal maka dapat menggunakan enhancer kimia maupun enhancer fisik. Enhancer kimia dapat diklasifikasikan berdasarkan struktur kimia atau berdasarkan mekanisme aksinya. Senyawa kimia yang memiliki gugus fungsi sama dapat memiliki mekanisme kerja yang berbeda tergantung dari sifat fisik-kimianya. Enhancer kimia dikategorikan berdasarkan struktur kimianya, antara lain: air, alkohol, amida, ester, eter alkohol, pirolidon, hidrokarbon, sulfoksida, surfaktan, terpen, fosfolipid, vesikel. Sedangkan enhancer fisik berupa penghantaran obat menggunakan energi eksternal untuk memberikan dorongan atau merusak secara fisik stratum korneum. Metode enhancer fisik seperti Iontoforesis, Elektroporasi, Magnetoforesis, Sonoforesis, Fotomekanik, Radiofrekuensi, Termoforesis, Microneedle, dan Jet Injektor.
\end{abstract}

Kata kunci: obat transdermal; penetrasi kulit; enhancer kimia; enhancer fisik 


\section{Pendahuluan}

Transdermal merupakan sistem penghantaran obat secara sistemik dengan mengaplikasikan obat ke permukaan kulit. Obat penetrasi melewati stratum korneum lalu ke lapisan yang lebih dalam, yakni epidermis dan dermis. Setelah mencapai dermis, obat masuk ke sirkulasi sistemik melalui mikrosirkulasi dermal [1].

Rute pemberian obat transdermal memiliki keterbatasan, yakni sulitnya penetrasi ke dalam kulit. Hal ini disebabkan oleh adanya stratum korneum yang menjadi barier utama masuknya obat ke dalam kulit. Penetrasi obat transdermal dapat mempengaruhi bioavailabilitasnya. Semakin sedikit obat yang berhasil penetrasi ke dalam kulit, maka bioavailabilitasnya menjadi lebih rendah. Struktur stratum korneum berupa "bata" dan "semen". Bata diidentifikasikan sebagai korneosit sedangkan semen diidentifikasikan sebagai matriks interselular lipid. Korneosit mengandung keratin yang saling cross-linked sedangkan interselular lipid mengandung ceramid, asam lemak, kolesterol yang tersusun membentuk kristalin lamellar bilayer (Gambar 1) [2].

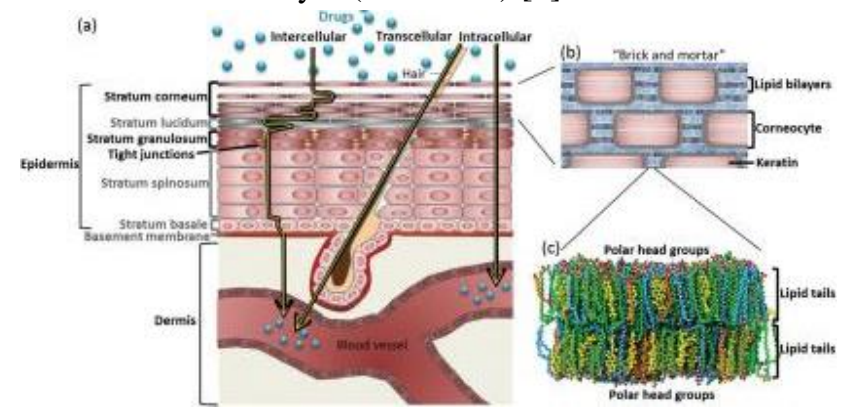

Gambar 1. Struktur Kulit (a) Lapisan Kulit (b) Stratum Korneum (c) Interselular Lipid [2]

Penetrasi obat ke dalam kulit dapat melalui rute transepidermal (trans-selular dan paraselular) dan rute transappendegeal (Gambar 2).

a) Rute Trans-epidermal

Rute trans-epidermal dibagi menjadi 2, yakni rute trans-selular dan paraselular. Pada rute trans-selular, molekul obat melewati korneosit dan interselular lipid secara lurus menembus epidermis. Sedangkan pada rute paraselular, obat hanya melewati interseluler lipid tanpa melewati keratinosit. Sebagian besar rute penetrasi transdermal melalui rute paraselular. Molekul polar dan non-polar berdifusi melalui rute trans-selular dan paraselular dengan mekanisme yang berbeda. Molekul polar sebagian besar berdifusi melalui jalur polar dengan mengikat air pada stratum korneum yang terhidrasi, biasanya lebih disukai melalui rute trans-selular. Sedangkan molekul non-polar $(\log \mathrm{P}>2)$ akan terlarut dan terdifusi melalui matriks lipid dari stratum korneum, biasanya lebih disukai melalui rute paraselular [3], [4].

b) Rute Trans-appendegal

Rute trans-appendegal adalah rute penetrasi obat melalui kanal/pori yang berasal dari folikel rambut atau kelenjar keringat. Meskipun rute ini memiliki permeabilitas yang tinggi, namun peranannya tidak terlalu besar karena luas area rambut di permukaan kulit hanya $0.1 \%$ dari total keseluruhan kulit. Rute ini biasanya untuk molekul ion dan molekul yang sangat polar sehingga sulit permeasi melalui stratum korneum [3], [4].

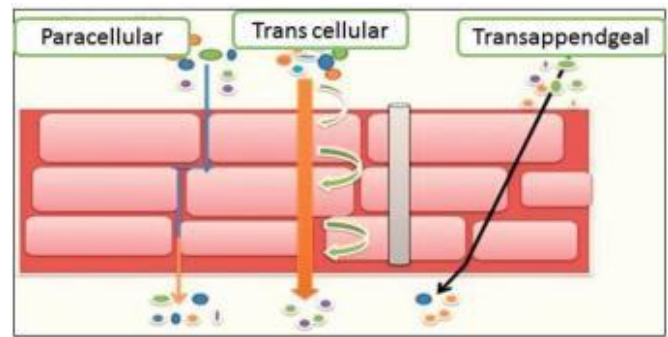

Gambar 2. Rute Penetrasi Obat Transdermal [4]

Sifat fisik-kimia dari molekul obat dapat menyebabkan terjadinya variasi kemampuan penetrasi obat ke dalam kulit. Sifat fisik-kimia obat dipengaruhi oleh koefisien partisi, ukuran molekul, kelarutan, titik leleh, kemampuan ionisasi, serta koefisien difusi. Selain itu, kemampuan pentrasi ke dalam kulit juga dipengaruhi oleh sistem penghantaran obatnya, seperti karakteristik perilisan, komposisi sistem penghantaran obat, serta kemampuan permeasi transdermal [4], [5]. Secara umum permeasi transdermal dapat ditingkatkan melalui 3 mekanisme, yaitu merusak atau mengubah sifat fisik-kimia stratum korneum, interaksi dengan interselular dalam stratum korneum, serta meningkatkan partisi obat dalam stratum korneum [6]. Untuk meningkatkan kemampuan permeasi transdermal dapat menggunakan enhancer kimia maupun enhancer fisik.

\section{Enhancer Kimia}

Senyawa kimia diketahui dapat berinteraksi dengan kulit dan dapat menembus struktur lipid bilayer. Terdapat lebih dari 300 senyawa kimia yang dapat berperan sebagai enhancer kimia untuk meningkatkan transport molekul obat ke dalam kulit, diantaranya: air, alkohol, amida, ester, eter alkohol, pirolidon, hidrokarbon, sulfoksida, surfaktan, terpenoid, fosfolipid, dan vesikel. Enhancer kimia memiliki keuntungan dari metode fisik karena lebih mudah diformulasi, mudah diaplikasikan, tidak memerlukan alat yang rumit, serta dapat digunakan sendiri oleh pasien. Enhancer kimia tidak hanya untuk meningkatkan penetrasi obat, tetapi juga dapat meningkatkan kelarutan obat, memberikan estetika, berperan 
sebagai pengemulsi, pengawet dan pengisi. Mekanisme aksi enhancer kimia dikategorikan berdasarkan aksinya pada stratum korneum. Enhancer kimia meningkatkan penetrasi obat ke dalam kulit dengan cara mengekstraksi lipid dari kulit sehingga merusak lipid lamella dan menyebabkan fluidisasi serta membentuk jalur difusi atau melakukan partisi senyawa kimia ke dalam lipid bilayer. Enhancer kimia juga dapat bekerja dengan cara meningkatkan aktivitas termodinamika pada formulasi [7].

Setelah sediaan transdermal diaplikasikan ke permukaan kulit, terjadi interaksi obat-enhancer kimia, enhancer kimiakulit, dan obat-kulit. Interaksi obat dan enhancer kimia berefek pada kecepatan dan jumlah perilisan obat dari pelarut. Interaksi obat-enhancer dapat dijelaskan dengan parameter kelarutan. Interaksi enhancer kimia dan kulit menyebabkan terjadi peningkatan ataupun penurunan penetrasi obat ke dalam kulit. Interaksi obat dan kulit dipengaruhi oleh sifat fisik-kimia obat seperti $\log \mathrm{P}$, titik leleh, dan kelarutan. Interaksi obat-palarut-kulit dapat dijelaskan oleh efek dorongan dan tarikan (Gambar 3) [8].

Efek dorongan terbagi menjadi 2 tipe. Jika perbedaan kelarutan antara obat dan enhancer kimia tinggi, maka atraksi obat menjadi lebih rendah dan obat akan lebih mudah terlepas dari enhancer kimia di dalam kulit. Interaksi yang dihasilkan akan lebih tinggi jika perbedaan parameter kelarutan antara obat dan enhancer kecil. Jika afinitas interaksi antara obat dan enhancer kimia tinggi maka kemampuan permeabilitasnya obat ke dalam kulit rendah sebab obat akan tertahan oleh enhancer kimia sehingga tidak dapat penetrasi melewati stratum korneum. Dengan meningkatkan aktivitas termodinamik, obat akan terdorong masuk ke stratum korneum oleh enhancer kimia. Efek tarikan dapat dijelaskan bahwa enhancer kimia merubah struktur transpormasi stratum korneum sehingga dapat meningkatkan kelarutan obat ke dalam stratum korneum atau membawa obat berdifusi melewati kulit [8].

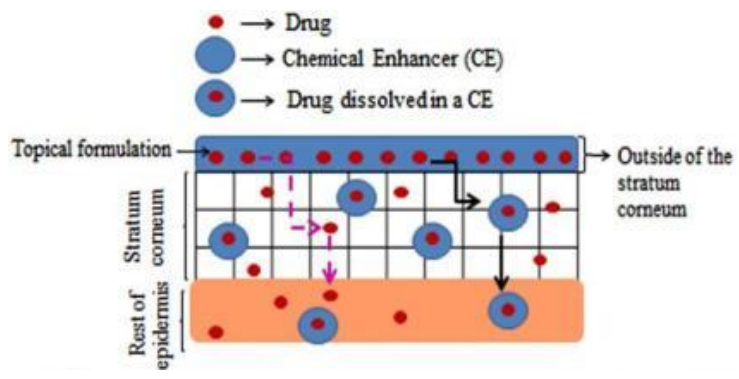

Gambar 3. Interaksi Enhancer Kimia, Obat dan Kulit [8]

Enhancer kimia idealnya memiliki sifat sebagai berikut: tidak toksik, tidak mengiritasi, tidak menimbulkan alergi, bekerja cepat, aktivitasnya dapat diprediksi dan reprodusibel, tidak menimbulkan efek farmakologi (inert), cepat pemulihan, dapat kompatibel dengan obat dan eksipien, serta idelanya tidak berbau dan tidak berwarna [9]. Enhancer kimia dapat diklasifikasikan berdasarkan struktur kimia atau berdasarkan mekanisme aksinya. Senyawa kimia yang memiliki gugus fungsi sama dapat memiliki mekanisme kerja yang berbeda tergantung dari sifat fisik-kimianya [7]. Beberapa enhancer kimia sebagai berikut:

\subsection{Air}

Air merupakan enhancer penetrasi alami. Hidrasi stratum korneum merupakan parameter penting untuk meningkatkan penetrasi obat karena meningkatkan fluks transdermal dari berbagai obat [7]. Pada kondisi normal, terdapat 10-20\% air di dalam stratum korneum. Natural Mosturizing Factor (NMF) berperan sebagai metdiator untuk sifat hidrosgopik di korneum. NMF mengandung asam amino bebas dan garamnya. Tingkat hidrasi epidermis sangat penting terhadap peningkatan permeasi karena menyebabkan keratin mengembang dan berefek pada kemasan lipid dengan menginterupsi pada jalur polar dan non-polar [4].

Air dapat meningkatkan permeasi obat hidrofilik dan lipofilik pada jalur trans-selular dan paraselular. Pada rute trans-selular, stratum korneum yang kering akan menjadi barier yang signifikan karena keberadaan beberapa ikatan hidrogen. Jika stratum korneum terhidrasi, konfigurasi protein menjadi terganggu sehingga air dapat berkompetisi dengan ikatan hidrogen pada protein yang menyebabkan berkurangnya interaksi antara ikatan hidrogen dan protein. Hal ini menyebabkan meningkatnya permeasi obat ke dalam kulit. Air berada dalam kuantitas yang sangat kecil pada gugus polar dari lipid bilayer. Kelebihan air yang diabsorpsi dari stratum korneum akan berada pada korneosit atau dapat berada sebagai fase terpisah dalam interselular [8].

\subsection{Alkohol}

Alkohol biasanya digunakan sebagai vesikel, pelarut, atau enhancer penetrasi. Alkohol dapat meningkatkan penetrasi kulit dengan berbagai mekanisme, seperti ekstraksi lipid dan protein, swelling dari stratum korneum, meningkatkan partisi obat ke dalam kulit atau meningkatkan kelarutan obat [7]. Pada konsentrasi tinggi, etanol mengekstraksi lipid dan protein dari stratum korneum sehingga membentuk pori pada stratum korneum. Etanol membantu penetrasi obat dengan meningkatkan kelarutan formula dan mengubah parameter kelarutan dari stratum korneum. Aktivitas termodinamika dari obat yang terlarut dalam etanol akan mendorong obat ke dalam stratum korneum sehingga mempercepat penetrasi obat ke stratum korneum [8].

\subsection{Amida}


Amida siklik dan asiklik dapat berperan untuk meningkatkan penetrasi obat. Amida biasanya digunakan sebagai pelarut atau meningkatkan partisi obat pada kulit. Azone merupakan senyawa sintetis enhancer permeasi pertama, memiliki 7 gugus polar dan rantai samping 12 karbon. Azone utamanya akan mengurangi resistensi difusi dari obat ke dalam stratum korneum, juga mengganggu struktur dari lipid bilayer. Azone dapat meningkatkan permeasi obat hidrofilik, hidrofobik, dan beberapa peptida. Konsentrasi efektif Azone pada konsentrasi kecil, yaitu 1-5\%. Meskipun Azone telah diteliti selama 25 tahun, namun belum digunakan untuk formulasi skala komersil.Urea dan analognya biasanya digunakan sebagai enhancer permeasi pada pelarut. Efeknya berbeda tergantung dari sistem pelarut yang dipilih, tetapi pada umumnya beraksi dengan merusak lipid pada kulit [7], [8].

\subsection{Ester}

Ester dapat meningkatkan permeasi berberapa obat ke dalam kulit. Isopropil miristat paling banyak digunakan sebagai enhancer kimia dan beberapa ester asam lemak. Mekanisme kerja ester umumnya dengan membentuk partisi dalam order lipid stratum korneum [7]. Isopropilmiristat memberikan fluidisasi dan menghambat lipid lamella. Selain itu juga menyebabkan segregasi fase dan ekstraksi lipid dan stratum korneum [8].

\subsection{Eter Alkohol}

Eter alkohol yang banyak digunakan adalah Transcutol. Transcutol merupakan enhancer kimia hidrofilik yang memiliki kelarutan yang sama dengan kulit. Mekanisme utamanya adalah meningkatkan partisi obat ke dalam kulit sehingga kelarutan dari Transcutol mendekati kelarutan kulit. Hal ini menyebabkan obat dapat permeasi dan terakumulasi di dalam kulit [8].

\subsection{Pirolidon}

Pirolidon yang banyak digunakan adalah N-metil-2pirolidon (NMP) dan 2-pirolidon (2P). Mekanismenya pada konsentrasi rendah adalah dengan cara berpartisi ke dalam korneosit melalui rute trans-selular dan pada konsentrasi tinggi berpartisi melalui rute paraselular. Pirolidon dapat melonggarkan kemasan lipid bilayer yang rapat serta menginduksi fluiditas lipid. Apabila pirolidon hidrofilik dan hidrofobik (NMP) bekerja pada daerah lipofilik maka pirolidon hidrofobik dapat menyebabkan eritema, iritasi kulit, ketebalan pada kulit sehingga dibatasi penggunaannya [8].

\subsection{Hidrokarbon}

Beberapa hidrokarbon seperti alkana, alkena, squalene, dan mineral oil digunakan sebagai vesikel untuk meningkatkan penetrasi obat ke dalam kulit. Mekanisme kerja hidrokarbon adalah dengan cara membentuk partisi ke dalam stratum korneum dan merusak struktur lipid bilayer [7].

\subsection{Sulfoksida}

Dimetil sulfoksida (DMSO) adalah senyawa kimia yang dipelajari sebagai enhancer permeasi. Biasanya digunakan sebagai pelarut untuk meningkatkan partisi obat ke dalam kulit [7]. Seperti pirolidin, DMSO berinteraksi dengan keratin ketika diaplikasikan pada konsentrasi rendah (20\%). DMSO merupakan molekul kecil sehingga mudah penetrasi ke daerah yang berprotein. Kemudian akan menggantikan protein-air dan menghambat konfigurasi natif dari protein dengan cara mengganggu ikatan hidrogen dan interaksi hidrofobik. DMSO dapat melonggarkan kemasan lipid sehingga dapat meningkatkan daerah aqueous pada rute paraselular dan membantu permeasi komponen hidrofilik [8].

\subsection{Surfaktan}

Surfaktan biasanya digunakan bersama dengan vesikel atau sistem pelarut. Aktivitasnya tergantung dari keseimbangan hidrofilik dan lipofilik, muatan, serta panjang ekor lipid. Surfaktan anion dan non-ionik paling banyak digunakan [7]. Surfaktan anion seperti SLS dapat meningkatkan permeasi melalui rute trans-selular dan paraselular, namun surfaktan anion paling sering menyebabkan iritasi dan kerusakan kulit. SLS menyebabkan stratum korneum mengembang sehingga stratum korneum dapat lebih banyak mengabsorpsi air lalu akan memudahkan penetrasi obat. SLS juga dapat membuka lipatan dan memanjangkan alfa keratin serta membuka jalur polar untuk permeasi obat. Surfaktan kation seperti amin, alkil-imidazolin, kuartenari amonium, dll dapat merusak susunan lipid stratum korneum lebih kuat dibandingkan dengan surfaktan anion dan non-ionik. Surfaktan kation juga dapat menyebabkan iritasi pada kulit. Surfaktan non-ionik biasa digunakan untuk kosmetik seperti cetyl atau stearil alkohol. Surfaktan non-ionik merusak stratum korneum lebih lemah dibandingkan surfaktan ionik sehingga lebih aman digunakan karena tidak terlalu mengiritasi kulit.Namun, efektivitas penetrasinya lebih kecil dibandingkan dengan jenis surfaktan lainnya [8].

\subsection{Terpen}

Terpen merupakan pilihan yang banyak digunakan sebagai enhancer permeasi pada penghantaran obat transdermal karena bersifat alami sehingga aman digunakan. Terpen banyak ditemukan pada essensial oil. Umumnya, terpen yang memiliki gugus non-polaryang lebih sedikit akan memiliki 
sifat enhancer permeasiyang lebih baik[7]. Molekul terpen dengan BM yang lebih rendah akan lebih efektif dibandingkan dengan BM yang lebih besar. Terpen yang bersifat polar meningkatkan penetrasi molekul hidrofilik sedangkan terpen yang bersifat non-polar meningkatkan penetrasi molekul hidrofobik dalam stratum korneum [8].

\subsection{Fosfolipid}

Fosfolipid berhasil digunakan sebagai enhancer kimia dalam bentuk vesikel, mikroemulsi, dan sistem micellar. Fosfolipid sebagai molekul individu tidak memiliki efek yang signifikan ketika berinteraksi dengan stratum korneum. Dalam bentuk struktur self-assembled, fosfolipid dapat menembus lipid bilayer dari stratum korneum sehingga meningkatkan partisi dari obat yang terenkapsulasi [7].

\subsection{Vesikel}

Vesikel adalah partikel koloid dalam bentuk bilayer dari molekul amfifilik/surfaktan yang berperan sebagai pembawa obat sehingga dapat membantu meningkatkan penetrasi obat. Komposisi vesikel mempengaruhi karakteristik fisikkimianya, seperti ukuran, muatan, fase termodinamika, lamellaritas, serta elastisitas bilayer. Karakteristik fisik-kimia ini akan mempengaruhi efektivitas vesikel dalam meningkatkan penetrasi obat transdermal. Beberapa mekanisme interaksi vesikel dan stratum korneum tergantung dari elastisitas dari vesikel. Interaksi antar komponen vesikel, serta interaksi antar vesikel dan kulit dipercaya bertanggungjawab terhadap peningkatan permeasi kulit dari sistem vesikel [7], [9].

a. Liposom

Liposom berupa struktur lipid bilayer berbentuk lingkaran dengan bagian inti kosong. Obat hidrofilik ditempatkan ke dalam inti liposom sedangkan obat lipofilik ditempatkan diantara bilayer (Gambar 4). Struktur liposom terbuat dari kolesterol dan fosfolipid. Liposom dapat bermuatan netral, negatif, atau positif tergantung dari gugus fungsi dan $\mathrm{pH}$ dari media. Keterbatasan liposom adalah tidak efektif untuk menghantarkan obat ke lapisan kulit yang lebih dalam [7], [9]. Contoh aplikasi liposom pada senyawa aktif curcumin yang dienkapsulasi dalam vesikel fosfatidilkolin [10].

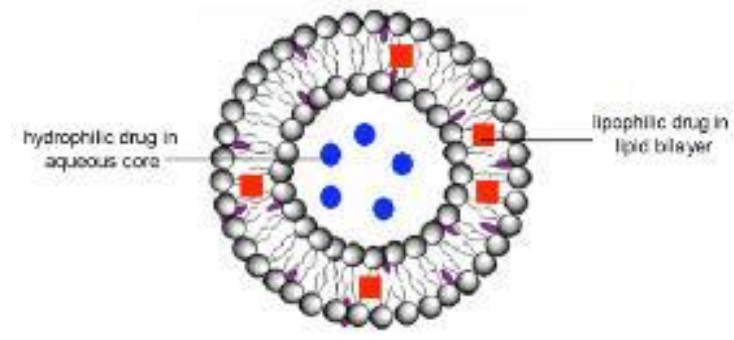

Gambar 4. Struktur Liposom [11]

b. Niosom

Niosom terdiri dari surfaktan non-ionik yang hampir mirip fungsinya dengan liposom. Berperan sebagai pembawa untuk aplikasi sejumlah obat dan kosmetik. Niosom mampu meningkatkan permeasi obat melintasi stratum korneum [7], [12]. Contoh aplikasi niosom pada obat Gallidermin untuk mempermudah absorpsi Gallidermin yang memiliki struktur molekul besar [13].

c. Transfersom

Transfersom terdiri dari fosfolipid yang mengandung surfaktan $10-25 \%$ dan etanol 3-10\%. Surfaktan berperan sebagai "edge activator" untuk meningkatkan deformabilitas bilayer. Transfersom dapat menembus brier stratum korneum secara spontan, dibandingkan dengan liposom karena terlalu besar untuk melewati pori dengan ukuran kurang dari $50 \mathrm{~nm}$ [12]. Contoh aplikasi transfersom kationik pada vaksin hepatitis B untuk menginduksi respon imun humoral dan selular secara topical [14].

d. Etosom

Etosom mengandung air, etanol, dan fosfolipid. Etosom mirip seperti liposom, namun etosom mengandung alkohol tinggi sehingga dapat meningkatkan penetrasi obat ke dalam jaringan dan sirkulasi sistemik. Alkohol dapat memfluidasi lipid etosom dan stratum korneum bilayer sehingga stratum korneum menjadi lebih lembut lalu memudahkan etosom untuk penetrasi ke dalam kulit [12]. Contoh aplikasi etosom pada Lamivudin untuk mempermudah melewati lipid serta meningkatkan ruang interselular lipid lamella dari stratum korneum [15].

e. Aquasom

Aquasom merupakan sistem pembawa obat padat yang baru ditemukan. Strukturnya terdiri dari tiga lapisan, yakni berupa inti, obat, dan penyalut, dihubungkan oleh ikatan non-kovalen, ionik, dan Van der Waals. Aquasom cocok untuk menghantarkan molekul protein dan peptida [12]. 


\section{Enhancer Fisik}

Keterbatasan enhancer adalah rendahnya efikasi, keamanan, kemampuan transport obat, serta banyaknya variasi. Maka dari itu, digunakan enhancer fisik atau metode secara aktif [2]. Metode ini dapat menghantarkan berbagai jenis obat ke dalam kulit menggunakan energi eksternal untuk memberikan dorongan atau merusak secara fisik stratum korneum. Dibandingkan dengan metode penghantaran pasif, enhancer fisik dapat secara efektif menghantarkan banyak jenis obat. Selain itu, enhancer fisik memiliki reprodusibilitas dalam mengontrol durasi pengobatan, juga dapat mengurangi lag time. [1]. Beberapa metode enhacer fisik sebagai berikut :

\section{1 lontoforesis}

Iontoforesis merupakan teknik non-invasif yang menggunakan modulasi dari intensitas dan durasi arus listrik. Iontoforesis memerlukan arus listrik lemah, yaitu sebesar 0.1$1.0 \mathrm{~mA} / \mathrm{cm}$ untuk mendorong obat masuk ke sirkulasi sistemik. Proses iontoforesis berdasarkan hukum Faraday, dimana semakin besar arus yang digunakan maka semakin besar pula jumlah obat yang penetrasi ke dalam kulit. Mekanisme iontophoresis dapat secara elektrorepulsif atau elektroosmosis. Pada mekanisme eletrorepulsif, terjadi penolakkan dari ion yang berada pada kutub yang bermuatan sama sehingga terjadinya dorongan menuju ke kutub yang bermuatan beda (Gambar 5).

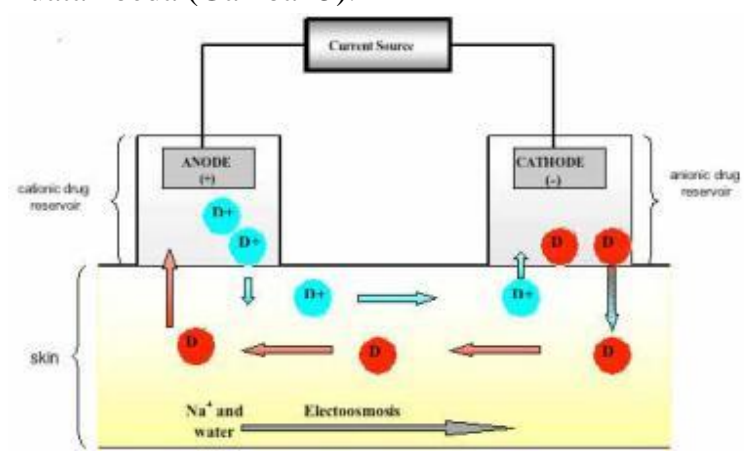

Gambar 5. Sistem Penghantaran Iontophoresis [11]

Obat yang bermuatan tidak mampu mencapai elektroda yang berlawanan karena obat memiliki berat molekul yang lebih besar sehingga tidak dapat mencapai elektroda yang berlawanan dan lebih mudah terbawa arus sirkulasi darah. Kemudian obat yang masuk sirkulasi darah dapat mencapai target aksinya sehingga menimbulkan respon terapetik. Sedangkan pada elektroosmosis, molekul netral ditranspor dengan aliran pelarut. Aplikasi secara elektroosmosis atau reverse-iontoforesis telah digunakan pada alat GlucoWatch untuk mengukur kadar glukosa darah dari cairan interstisial [1], [4], [5].

\subsection{Elektroporasi}

Elektroporasi menggunakan elektrik voltase tinggi sebesar 50-500 V dalam waktu yang singkat (Gambar 6). Voltase yang tinggi akan membentuk jalur/pori sehingga obat dapat melewati stratum korneum. Molekul kecil lipofilik dapat berpartisi ke dalam stratum korneum, tetapi molekul hidrofilik atau molekul bermuatan tidak dapat penetrasi secara signifikan [9].

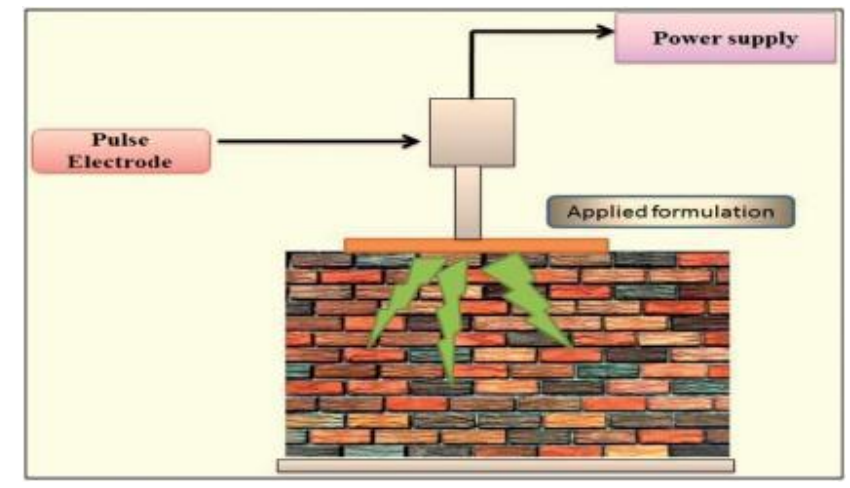

Gambar 6. Sistem Penghantaran Elektroporasi [4]

Pada elektroporasi irreversible, permeabilitas membran menyebabkan kerusakan besar pada homeostasis sel yang menyebabkan kematian sel, seperti nekrosi atau apoptosi. Pada elektroporasi reversible, hanya menimbulkan efek sementara untuk meningkatkan permeabilitas sehingga sel tetap hidup. Cara ini dapat digunakan pada penghantaran obat dan bioteknologi [1], [5]

\subsection{Magnetoforesis}

Magnetoforesis menggunakan medan magnet (5-450 mT) yang diaplikasikan pada sekeliling obat yang akan penetrasi ke dalam kulit (Gambar 7). Biasanya dikombinasikan dengan partikel magnetik sebagai pembawa obat untuk meningkatkan penghantaran obat. Mekanisme magnetoforesis secara magnetorepulsi, yaitu adanya dorongan yang dihasilkan oleh medan magnet dari pembawa obat sehingga obat dapat ditekan masuk ke dalam kulit. Perpindahan air dan molekul obat dibawah medan magnet eksternal disebabkan oleh dimagnetisme, yaitu sebuah kuantum efek mekanik yang terjadi pada semua material dan menginduksi medan magnet dalam jalur yang berlawanan ke medan magnet yang diaplikasikan secara eksternal. Perpindahan ini dapat membawa obat hidrofilik melintasi jaringan seperti epidermis [2]. 


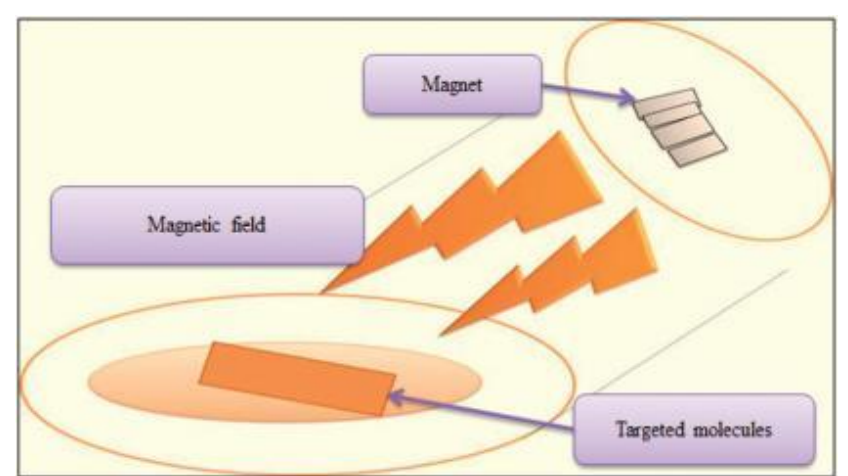

Gambar 7. Sistem Penghantaran Magnetoforesis [4]

\subsection{Sonoforesis}

Sonoforesis merupakan aplikasi menggunakan energi ultrasonik secara sementara untuk meningkatkan permeabilitas kulit (Gambar 8). Kekuatan frekuensi ultrasound tergantung dari kegunaannya, yakni untuk keperluan diagnosis (frekuensi tinggi, 3-10 MHz), terapi (frekuensi medium, 0,7-3 MHz), dan regulator (frekuensi rendah, 18-100 KHz). Penghantaran obat transdermal menggunakan frekuensi yang rendah untuk mengurangi efek samping. Ketika ultrasound diaplikasikan, energi secara parsial diabsorpsi. Pada tubuh manusia, energi diabsorpsi oleh jaringan yang menyebabkan temperatur lokal meningkat tergantung dari energi ultrasound yang diberikan, durasi pemaparan, serta kecepatan hilangnya panas oleh aliran darah atau konduksi. Resultan dari kenaikan temperatur pada kulit dapat meningkatkan permeabilitas karena adanya kenaikan difusivitas pada kulit. Selain itu, ultrasound juga dapat meningkatkan fluiditas dari lipid, serta meningkatkan permeasi melalui rute trans-selular lalu membentuk gelembung yang menyebabkan terbentuknya pori sebagai jalur masuknya molekul obat termasuk makromolekul seperti protein [4], [5].

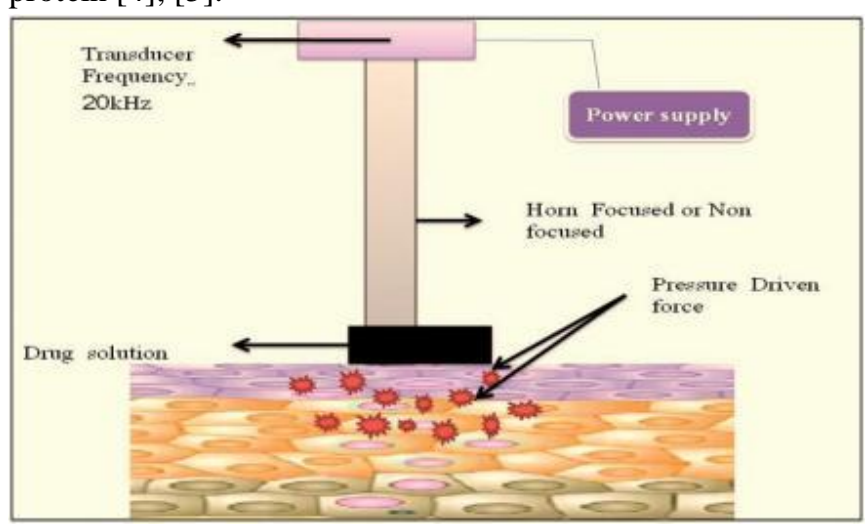

Gambar 8. Sistem Penghantaran Sonoforesis [4]

\subsection{Fotomekanik}

Teknik ini menggunakan laser untuk memberi tekanan pada gelombang yang dihasilkan dari bagian subtansi polistiren (Gambar 9). Teknik laser dapat menyebabkan terjadinya interaksi antara laser dan kulit sehingga dapat membantu meningkatkan fluks obat. Mekanisme yang terjadi dapat secara ablasi langsung dan melalui gelombang fotomekanik. Secara ablasi langsung, laser yang ditembakan akan membentuk pori pada stratum korneum. Irradiasi dari energi laser menyebabkan penguapan jaringan yang disebabkan oleh evaporasi cepat dari air dalam area yang iritasi diikuti dengan mikroeksplosi. Energi cepat ini hilang dari lokasi terablasi yang melindungi sekitar jaringan dari kerusakan yang diinduksi panas. Jumlah stratum korneum yang hilang dapat dikontrol dengan mengatur level energi yang diberikan pada kulit, terutama ketika diaplikasikan pada level energi rendah. Teknik ini dapat menghantarkan makromolekul yang sangat besar sampai $77.000 \mathrm{KDa}$ [4], [16].

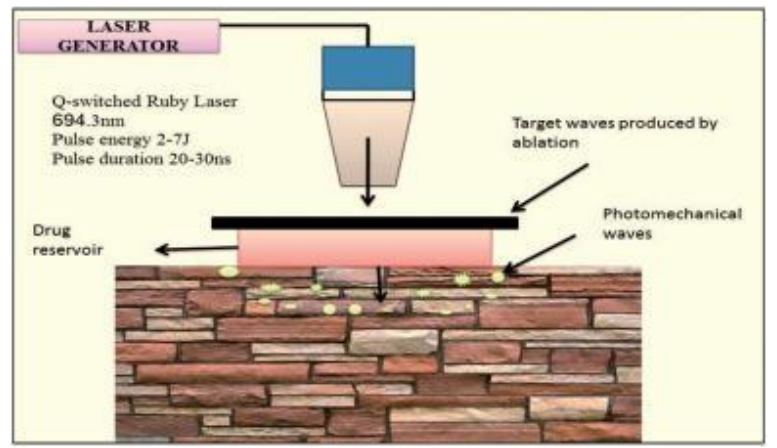

Gambar 9. Sistem Penghantaran Sonoforesis [4]

Gelombang fotomekanik bersifat kompresional unipolar yang ditimbulkan selama diberi radiasi laser secara intens. Gelombang ini berjumlah ratusan atmosfer dalam medan magnet yag dapat menyebabkan deformasi sel sehingga terjadi permeabilitas pada kulit meningkat [2].

\subsection{Radiofrekuensi}

Radiofrekuensi melibatkan elektroda seperti jarum yang secara langsung masuk ke dalam kulit lalu mengaplikasikan frekuensi tinggi arus bolak-balik (100 kHz). Mekanisme pengaplikasiannya dimulai dari menempelkan mikroelektroda ke permukaan kulit lalu kulit terjadi ablasi dengan adanya panas dari energi radiofrekuensi. Setelah dilepaskan dari kulit, terbentuk pori mikro sebagai jalur masuk obat. Teknik ini dapat diaplikasikan untuk obat hidrofilik dan makromolekul [1].

\subsection{Termoforesis}

Pada keadaan normal, permukaan kulit memiliki suhu $32^{\circ} \mathrm{C}$. Apabila dilakukan kenaikan suhu pada permukaan kulit, akan terjadi peningkatan fluks sebesar 2-3x lipat setiap kenaikan $7-8^{\circ} \mathrm{C}$. Peningkatan permeasi disebabkan oleh 
adanya peningkatan fluiditas lipid karena adanya panas dari peningkatan suhu. Vasodilatasi dari pembuluh darah subkutan sebagai respon homeostasis dari peningkatan suhu yang diberikan juga memiliki peranan penting terhadap peningkatan permeasi obat ke dalam kulit [12].

\subsection{Microneedle}

Microneedle merupakan teknik secara mekanik berupa jarum ukuran miron yang memilik panjang 100-500 $\mu \mathrm{m}$. Jarum dari sediaan microneedle hanya menembus sampai epidermis sehingga tidak menimbulkan rasa sakit. Microneedle membentuk jalur untuk dilewati oleh obat ke dalam kulit, obat yang dilepaskan kemudian menuju ke dermis lalu ke sirkulasi sistemik. Terdapat 4 jenis microneedle (Gambar 10), antara lain: solid microneedle, coated microneedle, dissolving microneedle dan hollow microneedle.
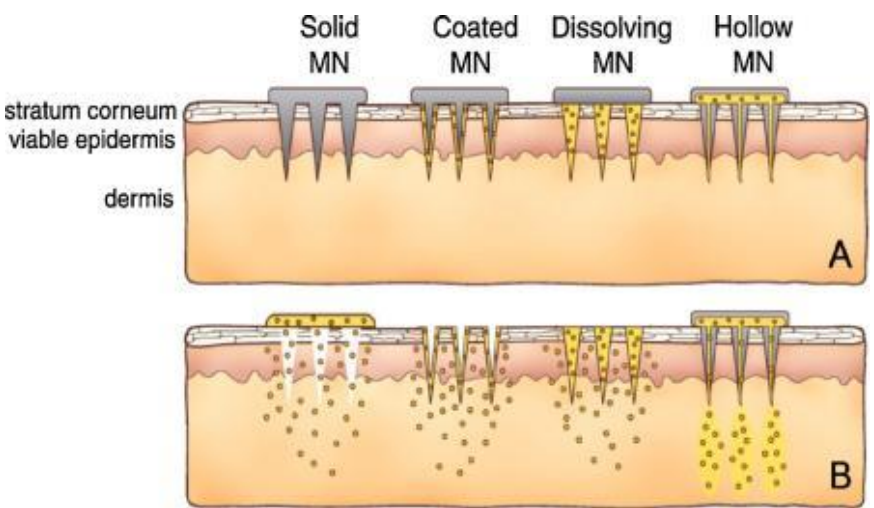

Gambar 10. Jenis Microneedle [17]

a. Solid Microneedle

Biasanya untuk pre-treatment, microneedle yang diaplikasikan tidak mengandung obat. Setelah jarum menembus kulit dan membentuk jalur ukuran mikron, obat kemudian aplikasikan ke permukaan kulit. Solid microneedle cocok digunakan untuk obat yang memerlukan volume besar karena pengaplikasiannya terpisah dari microneedle. Jarum yang biasa digunakan adalah jenis logam yang dapat disterilisasi tanpa merusak obat karena obat tidak dienkapsulasi pada microneedle. Solid microneedle dapat memicu eritema atau edema. Perlu dimonitoring waktu pemulihan dari jalur mikron yang terbentuk karena kemungkinan dapat menimbulkan infeksi oleh mikroba yang masuk melalui jalur tersebut [18], [19].

b. Coating Microneedle

Coating Microneedle adalah solid microneedle yang disalut dengan larutan penyalut yang mengandung obat. Larutan penyalut harus aman, tidak menimbulkan reaksi iritasi pada kulit. Jumlah obat yang dimasukkan tergantung dari ketebalan lapisan salut serta ukuran jarum. Ukuran jarum biasanya relatif kecil sehingga dosis obat yang dapat disalut hanya sedikit [18], [19].

c. Dissolving Microneedle

Dissolving Microneedle merupakan microneedle yang terbuat dari polimer biodegradable yang dienkapsulasi dengan obat. Microneedle yang penetrasi ke dalam kulit akan membentuk rongga sebagai jalur masuk obat dan jalur keluar cairan interstisial. Dissolving Microneedle yang mengandung polimer akan terlarut dalam cairan interstisial kulit kemudian obat dilepaskan menuju sirkulasi sistemik. Difusi obat terjadi oleh adanya kelembapan yang berasal dari cairan interstisial kulit. Dissolving Microneedle tidak menghasilkan limbah jarum karena terlarut di dalam tubuh. Namun keterbatasannya adalah perlu diperhatikan kekuatan jarum harus cukup menembus kulit dan distribusi jarum juga perlu diperhatikan agar tercapai efek terapi yang reprodusibel antar pasien [18], [19].

d. Hollow Microneedle

Hollow Microneedle memiliki jarum dengan celah ditengahnya sebagai tempat untuk diisi obat. Obat secara langsung dapat terdeposit ke dalam dermis. Sebagian besar digunakan untuk obat dengan berat molekul besar. Hollow microneedle memiliki drug loading yang lebih banyak tergantung dari celah kosong yang terdapat dalam microneedle. Celah kosong yang semakin besar akan meningkatkan flow rate serta mengurangi kekuatan dan ketajaman jarum [18], [19].

\subsection{Jet Injektor}

Jet injektor merupakan metode high-velocity particles yang mirip dengan injeksi hipodermik, tetapi tidak menimbulkan rasa sakit. Penghantaran obat ke dalam kulit dilakukan dengan cara menembakkan partikel cair atau padat dengan kecepatan supersonik melewati lapisan luar kulit menggunakan sumber energi yang sesuai. Alat powderject mengandung obat padat yang dimasukkan ke kulit menggunakan gas (helium) sebagai medium dengan kecepatan 600-900 m/s. Sedangkan liquid jet injector menggunakan tekanan tinggi untuk memasukkan tetesan cairan ke dalam kulit dengan kecepatan 100-200 m/s. Jenis jet injektor, antara lain : intra-ject, impla-ject, jet-syringe, il-ject, mini-ject, dan cross-ject [12], [20].

\section{Aplikasi Enhancer Transdermal}

Telah beberapa penelitian dilakukan untuk meningkatkan penetrasi obat ke dalam kulit, baik menggunakan enhancer kimia atau fisik, maupun kombinasi keduanya. Ronnander et al (2019) melakukan penelitian untuk meningkatkan daya penetrasi obat ke dalam kulit dengan kombinasi enhancer fisik 
antara DMN dan iontophoresis. Hasilnya memperlihatkan daya penetrasi dan perilisan obat lebih besar dibandingkan kelompok DMN tanpa iontophoresis. Kombinasi microneedle dan iontophoresis juga dapat menurunkan dosis yang digunakan menjadi lebih kecil sepertiga kalinya dari dosis terapetik [21].

\section{Kesimpulan}

Kemampuan penetrasi sediaan obat transdermal dipengaruhi oleh sifat fisik-kimia dari obat serta formulasi sediaannya. Faktor fisik-kimia yang harus diperhatikan dari zat aktif obat adalah koefisien partisi, ukuran molekul, kelarutan, titik leleh, kemampuan ionisasi, serta koefisien difusi. Formulasi sediaan obat dapat menambah kemampuan penetrasi obat transdermal melalui penambahan enhancer kimia atau menggunakan teknologi enhancer fisik. Enhancer kimia dikategorikan berdasarkan struktur kimianya, antara lain: air, alkohol, amida, ester, eter alkohol, pirolidon, hidrokarbon, sulfoksida, surfaktan, terpen, fosfolipid, vesikel. Sedangkan metode enhancer fisik yang dapat dilakukan seperti Iontoforesis, Elektroporasi, Magnetoforesis, Sonoforesis, Fotomekanik, Radiofrekuensi, Termoforesis, Microneedle, dan Jet Injektor. Dapat pula dilakukan kombinasi antar enhancer kima dan enhancer fisik untuk menambah kemampuan penetrasi obat transdermal ke dalam kulit sehingga efek yang dihasilkan juga meningkat.

\section{Ucapan Terima Kasih}

Penulis menyampaikan ucapan terima kasih kepada $\mathrm{Bu}$ Rina Kuswahyuning, M.Si., Ph.D., Apt atas ilmu yang telah diberikan tentang mata kuliah Sistem Penghantaran Obat Transdermal sehingga memotivasi penulis untuk menulis dan mempublikasikan artikel ini.

\section{Daftar Pustaka}

[1] A. Z. Alkilani, M. T. C. McCrudden, and R. F. Donnelly, "Transdermal drug delivery: Innovative pharmaceutical developments based on disruption of the barrier properties of the stratum corneum," Pharmaceutics, vol 7, no. 4, pp. 438-470, 2015, doi: 10.3390/pharmaceutics7040438.

[2] R. Yang, T. Wei, H. Goldberg, W. Wang, K. Cullion, and D. S. Kohane, "Getting Drugs Across Biological Barriers," Adv. Mater., vol. 29, no. 37, 2017, doi: 10.1002/adma.201606596.

[3] H. Tanwar, "A Review: Physical Penetration Enhancers For Transdermal Drug Delivery Systems," IOSR J. Pharm. Biol. Sci. e-ISSN, vol. 11, no. 1, pp. 101-105, 2016, doi: 10.9790/3008-1111101105.

[4] H. Marwah, T. Garg, A. K. Goyal, and G. Rath, "Permeation enhancer strategies in transdermal drug delivery," Drug Deliv., vol. 23, no. 2, pp. 564-578, 2016, doi: 10.3109/10717544.2014.935532.

[5] L. N. Carpentieri-Rodrigues, J. M. Zanluchi, and I. H. Grebogi, "Percutaneous absorption enhancers: Mechanisms and potential," Brazilian Arch. Biol. Technol., vol. 50, no. 6, pp. 949-961, 2007, doi: $10.1590 / \mathrm{S} 1516-89132007000700006$.

[6] H. Benson, "Transdermal Drug Delivery: Penetration Enhancement Techniques," Curr. Drug Deliv., vol. 2, no. $1, \quad$ pp. 23-33, 2005, doi: 10.2174/1567201052772915

[7] P. Karande and S. Mitragotri, "Enhancement of transdermal drug delivery via synergistic action of chemicals," Biochim. Biophys. Acta - Biomembr., vol. 1788, no. 11, pp. 2362-2373, 2009, doi: 10.1016/j.bbamem.2009.08.015.

[8] T. Haque and M. M. U. Talukder, "Chemical enhancer: A simplistic way to modulate barrier function of the stratum corneum," Adv. Pharm. Bull., vol. 8, no. 2, pp. 169-179, 2018, doi: 10.15171/apb.2018.021.

[9] J. Juan, I. Marlen, and C. Luisa, "Chemical and Physical Enhancers for Transdermal Drug Delivery," Pharmacology, 2012, doi: 10.5772/33194.

[10] P. Basnet, H. Hussain, I. Tho, and N. Skalko-Basnet, "Liposomal Delivery System Enhances AntiInflammatory Properties of Curcumin," J. Pharma Sci, vol. 101, pp. 598-609, 2012, doi: 10.1002/jps.22785.

[11] D. I. . Morrow, P. . McCarron, A. . Woolfson, and R. . Donnelly, "Innovative Strategies for Enhancing Topical and Transdermal Drug Delivery," Open Drug Deliv. J., vol. 64, no. 14, p. 220, 2007, doi: 10.1016/j.addr.2012.04.005.Microneedles.

[12] V. Mathur, Y. Satrawala, and M. S. Rajput, "Physical and chemical penetration enhancers in transdermal drug delivery system," Asian J. Pharm., vol. 4, no. 3, pp. 173183, 2010, doi: 10.4103/0973-8398.72115.

[13] A. Manosroi, P. Khanrin, and W. Lohcharoenkal, "Transdermal absorption enhancement through rat skin of gallidermin loaded in niosomes," Int J Pharm, vol. 392, no. 304-310, 2010, doi: https://doi.org/10.1016/j.ijpharm.2010.03.064.

[14] N. Li, L. Peng, and X. Chen, "Antigen-loaded nanocarriers enhance the migration of stimulated Langerhans cells to draining lymph nodes and induce effective transcutaneous immunization," Nanomedicine Nanotechnology, Biol. Med., vol. 19, no. 1, pp. 215-223, 2014, doi: https://doi.org/10.1016/j.nano.2013.06.007.

[15] S. Jain, A. K. Tiwary, and N. K. Jain, "Formulation and evaluation of ethosomes for transdermal delivery of lamivudine," AAPS PharmSciTech, vol. 8, pp. 249-257, 2007, doi: https://doi.org/10.1208/pt0804111.

[16] R. . Donnelly and T. R. . Singh, Novel Delivery Systems for Transdermal and Intradermal Drug Delivery. UK: John WIley and Sons, LLd, 2015.

[17] K. Ita, "Dissolving microneedles for transdermal drug delivery: Advances and challenges," Biomed. Pharmacother., vol. 93, pp. 1116-1127, 2017, doi: 10.1016/j.biopha.2017.07.019.

[18] Y. Kim, J. Park, and M. R. Prausnitz, "Microneedles for 
drug and vaccine delivery ," Adv. Drug Deliv. Rev., vol. 64, no. 14, pp. 1547-1568, 2012, doi: 10.1016/j.addr.2012.04.005.

[19] S. Dharadhar, A. Majumdar, S. Dhoble, and V. Patravale, "Microneedles for transdermal drug delivery: a systematic review," Drug Dev. Ind. Pharm., vol. 45, no. 2, pp. 188-201, 2019, doi: 10.1080/03639045.2018.1539497.

[20] H. A. E. Benson, J. E. Grice, Y. Mohammed, S. Namjoshi, and M. S. Roberts, "Topical and Transdermal Drug Delivery: From Simple Potions to Smart Technologies," Curr. Drug Deliv., vol. 16, no. 5, pp. 444-460, 2019 ,

doi: $10.2174 / 1567201816666190201143457$.

[21] J. P. Ronnander, L. Simon, and A. Koch, "Transdermal Delivery of Sumatriptan Succinate Using Iontophoresis and Dissolving Microneedles," J. Pharm. Sci., vol. 108, no. 11 , pp. 3649-3656, 2019, doi: 10.1016/j.xphs.2019.07.020. 